\title{
THE HERPETOLOGICAL COLLECTION OF ZOOLOGY MUSEUM, ISTANBUL UNIVERSITY
}

\author{
Nilgün KAYA ${ }^{1, *}$, Oya ÖZULUĞ ${ }^{2}$ \\ ${ }^{1}$ Institute of Graduate Studies in Science and Engineering, İstanbul University, 34134, Vezneciler, İstanbul, Turkey \\ $2 \cdot$ Department of Biology, Faculty of İstanbul University, 34134, Vezneciler, İstanbul, Turkey
}

\begin{abstract}
Amphibia and Reptilia collections at the Zoological Museum, University of Istanbul (ZMUI) were studied and revised. The samples were collected from 1921 until today. The localities of most species are found in the different regions of Turkey. The collection have 75 species of which 21 species are amphibians and 54 species are reptiles. With this study a zoological collection belong to ZMUI was given for the first time.
\end{abstract}

Keywords: Zoology Museum, Collection, Taxonomy, Amphibians, Reptiles

İSTANBUL ÜNIVERSITESİ ZOOLOJI MÜZESI HERPETOLOJIK KOLEKSIYYNU ÖZET

İstanbul Üniversitesi Zooloji Müzesi (ZMUI) Amphibia ve Reptilia koleksiyonu çalışıldı ve revize edildi. Örnekler 1921 yılından günümüze kadar toplanmıştır. Çoğu türün lokalitesi Türkiye'nin farklı bölgelerindendir. Koleksiyonda 75 tür bulunmakta olup bunların 21 türü amfibi ve 54 türü sürüngenlerdendir. Bu çalışma ile ilk defa ZMUI'a ait bir zoolojik koleksiyon verilmiştir.

Anahtar Kelimeler: Zooloji Müzesi, Koleksiyon, Taksonomi, Kurbağa, Sürüngen

\section{INTRODUCTION}

The Zoological museum collection is quite important for taxonomists. Because Istanbul University is the oldest university of Turkey, it became the host for first studies in the field of zoology, collections of the Zoological Museum of Istanbul University are the oldest ones in Turkey. These collections are valuable for reflecting the history of zoology in Turkey. The Zoology museum was first established to support education in the field of zoology. Between the years 1934 and 1949, as a result of the thorough taxonomic studies of Prof. Dr. Curt Kosswig a German scientist who has been working at the Zoology Institute (a name, used during that period) and his students, collections have been enriched and also the zoology museum has reached an international standard. Besides the material that has been collected for scientific studies, there are also specimens which have been obtained from abroad or sent abroad and which don't belong to Turkish fauna. There are samples in the herpetological collection which date back to the years 1921-2016. While the list of herpetological collection was being prepared, the listing of all the samples that are found at our museum was compiled by studying the samples whose taxonomic status hasn't yet been determined. This Herpetological collection is being reported from Turkey for the first time within this study. Until now, only the list of fish collections which belong to Istanbul University Hydrobiology Museum (IUSHM) has been published in our country [1]. In other counrties, some of the museums were published their herpetological collection [2, $3,4,5,6]$. Our purpose on publishing the herpetological collection list is to inform domestic and foreign scientist whose studies require the samples we have. Various publications have been published 
about the herpetofauna in our country. In 1944 an article on Turkey's herpetofaunal studies entitiled "Introduction into the knowledge of the Amphibia and Reptilia of Turkey" was published by Bodenheimer [7] and followed by other publications about the herpetofauna of Anatolia and Thracea follows by Mertens [8], Baran and Atatür [9]. Although there are several publications on the herpetofauna of Turkey, majority of these papers lack the information about the collections or the samples' status of preservation. Because of that reason any study aimed to compare specimens with these previous studies fails to find comparison material easily.

\subsection{The History of İstanbul University Zoology Museum}

The Zoology museum's history dates back to the 1920s when education began in the field of zoology. At this time, most of the zoological materials were collected to support education. The Zoology Museum and the Institute of Zoology continued to develop in 1933 after the establishment of the republic in Turkey following the new regulations regarding universities and the politics of education. Andre Naville (1933 - 1937) and Prof. Dr. Curt Kosswig (1937 - 1947) were directors of Zoology Institute. At that time the academic staff and the collection of zoology museum were improved. In 1957 the upper floors of the building where the zoology museum was located, were destroyed due to the government decision, after that the collections of the zoology museum were stored in Muratpaşa Madrasah until a new biology building was completed. Most of the materials were damaged during the move. Despite the completion of a new building in 1973, the zoology museum was only able to be opened between 1985 - 1989. Some samples were used in our exhibition part of the museum but with no information about where and when they were found. Also in this section some invertebrates and birds which were kept at Yildız Palace during the time of Sultan Abdülhamit are on display. Nowadays the museum can be found on the upper floor of the biology department in Beyazit, Istanbul [10].

\section{MATERIALS AND METHODS}

Amphibian and reptile collections were examined in the Zoology Museum of Istanbul University (ZMUI). Materials were nominated with the classification of Başoğlu and Baran [11], Özeti and Y1lmaz [12], Baran and Atatür [9], Sindaco [13], Sindaco et al. [14]. Localities and dates of each samples were noted using the original labels. These samples were subjected to redescription and revision. After they were studied, each species was transfered to new jars. $70 \%$ ethyl alcohol or $10 \%$ formalin was used for renewing chemicals in jars. Keeping the original label, a new label which is resistant to alcohol and formaldehyde was also prepared. A new museum number was given to each species, followed by the abbreviation of class name, year of study and numbers of each jar, although museum numbers were given formerly for some of the materials in the section of exhibition.

\section{RESULTS}

The Zoology Museum of Istanbul University (ZMUI) has the oldest materials collected most of them from Turkey. In this study, a total of 75 species of which 21 of them are Amphibia and 54 are Reptilia species are listed. Fourty - three of them having locality and date information are listed in (Table 1). Photos of some Amphibia and Reptilia species are given in Figure 1., Figure 2. and Figure 3. 
Kaya and Özuluğ / Anadolu Univ. J. of Sci. and Technology C-Life Sci. and Biotech. 6 (2)-2017

Table 1. List of herpetological collection of Zoology Museum, Istanbul University $\left(*\right.$ Det. Bodenheimer, ${ }^{\star}$ Det. Bodenheimer, Leg. Kosswig, ${ }^{\star}$ Det. Bodenheimer, Leg. Hovasse, • Leg. Bodenheimer, Det. Bodenheimer).

\begin{tabular}{|c|c|}
\hline Species & Museum Number and Locality \\
\hline \multicolumn{2}{|l|}{$\begin{array}{l}\text { Class Amphibia Linnaeus, } 1758 \\
\text { Order Urodela Duméril, } 1805 \\
\text { Family Salamandridae Goldfuss, } 1820\end{array}$} \\
\hline Lissotriton vulgaris (Linnaeus, 1758) & Amp-13-001 (3 spc.), April 2012, İstanbul. \\
\hline Ommatotriton ophryticus (Berthold, 1846) & Amp-14-001(5 spc.), 23.03.2014, Düzce. \\
\hline Triturus ivanbureschi (Strauch, 1870) & Amp-13-002 (1 spc.), 1961, Jordan. \\
\hline \multicolumn{2}{|l|}{ Order Anura Fischer von Waldheim, 1813} \\
\hline \multicolumn{2}{|l|}{ Family Bombinatoridae Gray, 1831} \\
\hline Bombina bombina (Linnaeus, 1761) & Amp-13-019 (1 spc.), 16.07.1985, Kirklareli. \\
\hline \multicolumn{2}{|l|}{ Family Bufonidae Gray, 1825} \\
\hline Bufo bufo (Linnaeus, 1758) & Amp-14-002 (3 spc.), March 2014, Düzce, \\
\hline Bufotes viridis (Laurenti, 1768) & $\begin{array}{l}\text { Amp-13-003 (2 spc.), August 1999, Edirne; } \\
\text { Amp-13-004 (1 spc.) July 1999, Edirne. }\end{array}$ \\
\hline Bufotes variabilis (Pallas, 1769) & $\begin{array}{l}\text { Amp-13-005 (1 spc.), August 2010, Sivas; } \\
\text { Amp-13-020 (9 spc.), 02.02.1966, Antalya; } \\
\text { Amp-13-021 (2 spc.), 03.02.1966, Antalya; } \\
\text { Amp-13-022 (1 spc.), 08.02.1966, Alanya. }\end{array}$ \\
\hline \multicolumn{2}{|l|}{ Family Hylidae Rafinesque, 1815} \\
\hline Hyla orientalis (Bedriaga, 1890$)$ & Amp-13-023 (1 spc.), 12.04.1965, Balıkesir. \\
\hline Hyla savignyi (Audouin, 1827) & $09-182$ (1 spc.), July 1939, Elazığ \\
\hline \multicolumn{2}{|l|}{ Family Pelobatidae Lataste 1879} \\
\hline Pelobates syriacus Boettger, 1889 & Amp-13-024 (1 spc.), February 1972, Izmir. \\
\hline \multicolumn{2}{|l|}{ Family Ranidae Rafinesque, 1814} \\
\hline Rana dalmatina Bonaparte, 1840 & $\begin{array}{l}\text { Amp-13-017 (2 spc.), 22.12.1960, İstanbul; } \\
\text { Amp-13-018 (16 spc.), 01.03.1961, İstanbul; } \\
\text { Amp-13-006 (11 spc.), 01.06.1984, İstanbul; } \\
\text { Amp-13-007 (1 spc.), 19.07.1961, Kurklareli; } \\
\text { Amp-13-008 (2 spc.), 22.08.2012, İstanbul; } \\
\text { Amp-13-037 (3 spc.), 18.07.1985, Kurklareli. }\end{array}$ \\
\hline Rana macrocnemis Boulenger, 1885 & $\begin{array}{l}\text { Amp-13-016 (1 spc.), August 1941, Erciyes } \\
\text { Amp-14-003 (3 spc.), 27.06.2014, Düzce. }\end{array}$ \\
\hline Pelophylax bedriagae (Camerano, 1882) & $\begin{array}{l}\text { Amp-13-025 (1 spc.), 31.01.1966, Antalya; } \\
\text { Amp-13-026 (4 spc.), 01.02.1966, Antalya; } \\
\text { Amp-13-027 (1 spc.), 04.02.1966, Antalya; } \\
\text { Amp-13-028 (4 spc.), 04.02.1966, Alanya; } \\
\text { Amp-13-029 (1 spc.), 06.02.1966, Alanya; } \\
\text { Amp-13-030 (2 spc.), 08.02.1966, Alanya; } \\
\text { Amp-13-031 (2 spc.), 08.02.1966, Antalya; } \\
\text { Amp-13-032 (1 spc.), 14.02.1965, İzmir. }\end{array}$ \\
\hline Pelophylax ridibundus (Pallas, 1771) & $\begin{array}{l}\text { 09-144 (1 spc.), July 1941, Konya*; } \\
\text { Amp-13-009 (8 spc.), 19.07.1961, Kirklareli; } \\
\text { Amp-13-033 (1 spc.), 12.04.1965, Balıkesir; } \\
\text { Amp-13-034 (15 spc.), 15.04.1965, Balıkesir; } \\
\text { Amp-13-035 (13 spc.), 23.04.1965, Balıkesir; } \\
\text { Amp-13-036 (5 spc.), 23.04.1965, Balıkesir. }\end{array}$ \\
\hline \multicolumn{2}{|l|}{$\begin{array}{l}\text { Class Reptilia Linnaeus, } 1758 \\
\text { Order Testudines } \\
\text { Family Geoemydidae }\end{array}$} \\
\hline Mauremys rivulata (Valenciennes, 1833) & Rept-16-001(1 spc.), 26.05.2016, İstanbul. \\
\hline \multicolumn{2}{|l|}{ Order Squamata Oppel, 1811} \\
\hline Stellagama stellio (Linnaeus, 1758 ) & $\begin{array}{l}\text { Rept-13-001 (2 spc.), 1961, Jordon; } \\
\text { Rept-13-056 (6 spc.), 01.02.1966, Antalya; } \\
\text { Rept-13-057 (9 spc.), 07.02.1966, Alanya. }\end{array}$ \\
\hline
\end{tabular}


Kaya and Özuluğ / Anadolu Univ. J. of Sci. and Technology C-Life Sci. and Biotech. 6 (2)-2017

\begin{tabular}{|c|c|}
\hline Trapelus ruderatus (Olivier, 1804) & Rept-13-037 (1 spc.), July 1941, Van ${ }^{\bullet}$. \\
\hline \multicolumn{2}{|l|}{ Family Anguidae Gray, 1825} \\
\hline Anguis fragilis Linnaeus, 1758 & $\begin{array}{l}\text { Rept-13-002 (1 spc.), 28.08.1980, Kastamonu; } \\
\text { Rept-13-003 (3 spc.), March 1981, İstanbul; } \\
\text { Rept-13-004 (1 spc.), 1.06.1984, İstanbul; } \\
\text { Rept-13-005 (1 spc.), 21.04.2012, İstanbul. }\end{array}$ \\
\hline \multicolumn{2}{|c|}{ Family Chamaeleonidae Hardwicke \& Gray, 1828} \\
\hline Chamaeleo chamaeleon (Linnaeus, 1758) & Rept-13-006 (2 spc.), 29.10.1960, İzmir. \\
\hline \multicolumn{2}{|l|}{ Family Gekkonidae Bonaparte, 1831} \\
\hline Mediodactylus kotschyi (Steindachner, 1870) & Rept-13-007 (1spc.), 18.07.1985, Kirklareli. \\
\hline Hemidactylus turcicus (Linnaeus, 1758) & $\begin{array}{l}\text { Rept-13-008 (1 spc.), 3.07.1962, Kırklareli; } \\
\text { Rept-13-009 (1 spc.), 2003, İzmir; } \\
\text { Rept-13- } 010 \text { (1 spc.), 26.09.2011, İstanbul; } \\
\text { Rept-13-011 (1 spc.), 3.01.2012, İstanbul; } \\
\text { Rept-13-058 (1 spc.), 08.04.1973, İzmir. }\end{array}$ \\
\hline \multicolumn{2}{|l|}{ Family Lacertidae Bonaparte, 1831} \\
\hline Darevskia saxicola (Eversmann, 1834) & Rept-13-039 (2 spc.), July 1940, Trabzon.* \\
\hline Darevskia valentini (Boettger, 1892) & Rept-13-016 (2 spc.), 2010, Sivas. \\
\hline Darevskia praticola $($ Eversmann, 1834) & Rept-13-015 (1 spc.), 18.07.1985, Kirklareli. \\
\hline Lacerta agilis Linnaeus, 1758 & Rept-13-012 (1 spc.), 18.09.1979, Erzurum. \\
\hline Lacerta viridis (Laurenti, 1768) & Rept-13-013 (2 spc.), 18.07.1985, Kırklareli. \\
\hline Lacerta trilineata Bedriaga, 1886 & Rept-16-002 (1 spc.), 06.04.2016, İstanbul. \\
\hline Ophisops elegans (Menetries, 1832) & $\begin{array}{l}\text { Rept-13-018 (1 spc.), 18.07.1985, Kirklareli; } \\
\text { Rept-13-019 (15 spc.), 28.09.1971, Imbros. }\end{array}$ \\
\hline Parvilacerta parva (Boulenger, 1887) & Rept-13-014 (1 spc.), 18.07.1985, Kırklareli. \\
\hline Podarcis muralis (Laurenti, 1768) & Rept-13-021 (2 spc.), 18.07.1985, K1rklareli. \\
\hline Podarcis taurica ( Pallas, 1814 ) & Rept-13-023 (1 spc.), 23.10.2010, İstanbul. \\
\hline Podarcis siculus hierophyhica & Rept-13-042 (1 spc.), May 1940, Hayırsız Island.* \\
\hline \multicolumn{2}{|l|}{ Family Scincidae Gray, 1825} \\
\hline Ablepharus kitaibelii (Bibron - Bory, 1833) & Rept-13-024 (1 spc.), 17.06.2011, Istanbul. \\
\hline Trachylepis vittata (Linnaeus, 1758) & Rept-13-025 (2 spc.), 1961, Jordan. \\
\hline \multicolumn{2}{|l|}{ Suborder Ophidia Linnaeus, 1758} \\
\hline \multicolumn{2}{|l|}{ Family Boidae Gray, 1825} \\
\hline Eryx jaculus (Linnaeus, 1758) & $09-117$ (1 spc.), 1926, Istanbul *. \\
\hline \multicolumn{2}{|l|}{ Family Colubridae Oppel, 1811} \\
\hline Dolichophis jugularis (Linnaeus, 1758) & Rept-13-026 (1 spc.), 2003, İzmir. \\
\hline Platyceps najadum (Eichwald, 1831) & Rept-13-047 (1 spc.), 1960, Ağr1. \\
\hline Hemorrhois ravergieri (Ménétriés, 1832) & Rept-13-048 (1 spc.), 22.05.1966, Yalova. \\
\hline Zamenis longissimus (Laurenti, 1768) & Rept-13-049 (1 spc.), Nowember 1940, Trabzon*. \\
\hline Zamenis hohenackeri (Strauch, 1873) & Rept-13-027 (1 spc.), 05.08.1966, Adana. \\
\hline \multicolumn{2}{|l|}{ Family Natricidae Bonaparte, 1840} \\
\hline Natrix natrix (Linnaeus, 1758) & $\begin{array}{l}\text { Rept-13-028 (1 spc.), 27.05.1980, İstanbul; } \\
\text { Rept-13-029 (1 spc.), 7.10.1996, Iğdır. }\end{array}$ \\
\hline Natrix tessellata (Laurenti, 1768 ) & $\begin{array}{l}\text { Rept-13-053 (1 spc.), July 1926, İstanbul*; } \\
09-132 \text { (1 spc.), July 1941, Kayseri ‘; } \\
\text { Rept-13-030 (1 spc.), 27.05.1980, İstanbul; } \\
\text { Rept-13-031 (1 spc.), 04.05.2012, İstanbul. }\end{array}$ \\
\hline \multicolumn{2}{|l|}{ Family Lamprophiidae Fitzinger, 1843} \\
\hline Malpolon monspessulanus (Hermann, 1804) & Rept-13-054 (1 spc.), June 1921, İstanbul ${ }^{\mathbf{\Delta}}$. \\
\hline \multicolumn{2}{|l|}{ Family Typhlopidae Merrem, 1820} \\
\hline Xerotyphlops vermicularis (Merrem, 1820) & $\begin{array}{l}\text { Rept-13-032 (1 spc.), 27.05.2009, Marmara Island; } \\
\text { Rept-13-033 (1 spc.), 20.06.1984, İstanbul. }\end{array}$ \\
\hline
\end{tabular}


Kaya and Özuluğ / Anadolu Univ. J. of Sci. and Technology C-Life Sci. and Biotech. 6 (2)-2017

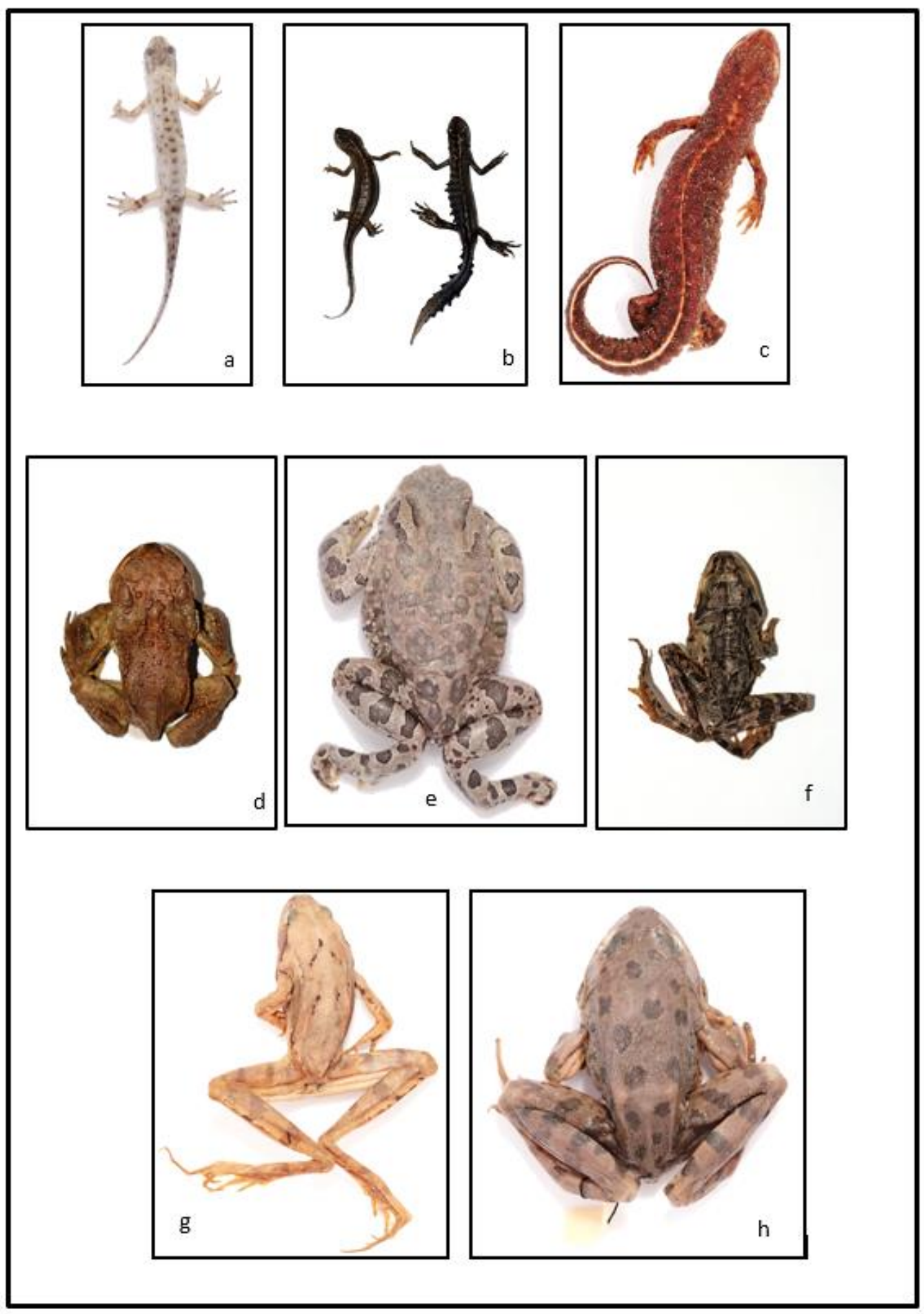

Figure 1. Photos of Amphibia species (a:Lissotriton vulgaris, b:Ommatotriton ophryticus (female,male), c:Triturus ivanbureschi, d:Bufo bufo, e:Bufo viridis, f:Rana macrocnemis, g:Rana dalmatina, $\mathrm{h}:$ Pelophylax ridibundus). 


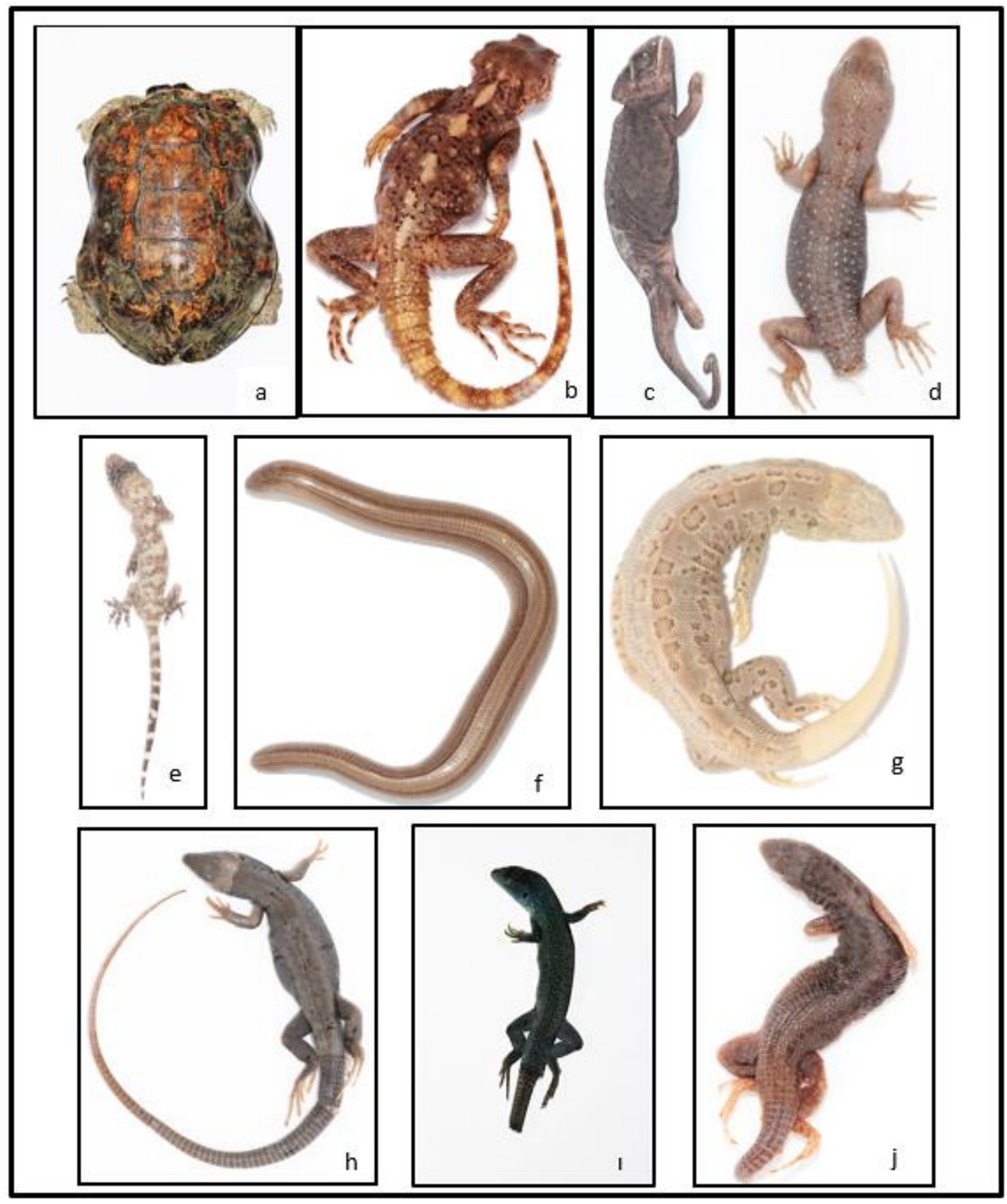

Figure 2. Photos of Reptilia species (a:Mauremys rivulata, b:Stellagama stellio, c:Chamaeleo chamaeleon, $\mathrm{d}:$ Mediodactylus kotschyi, e:Hemidactylus turcicus, f:Anguis fragilis, g:Lacerta agilis, h:Lacerta viridis, 1:Lacerta trilineata, i:Parvilacerta parva). 


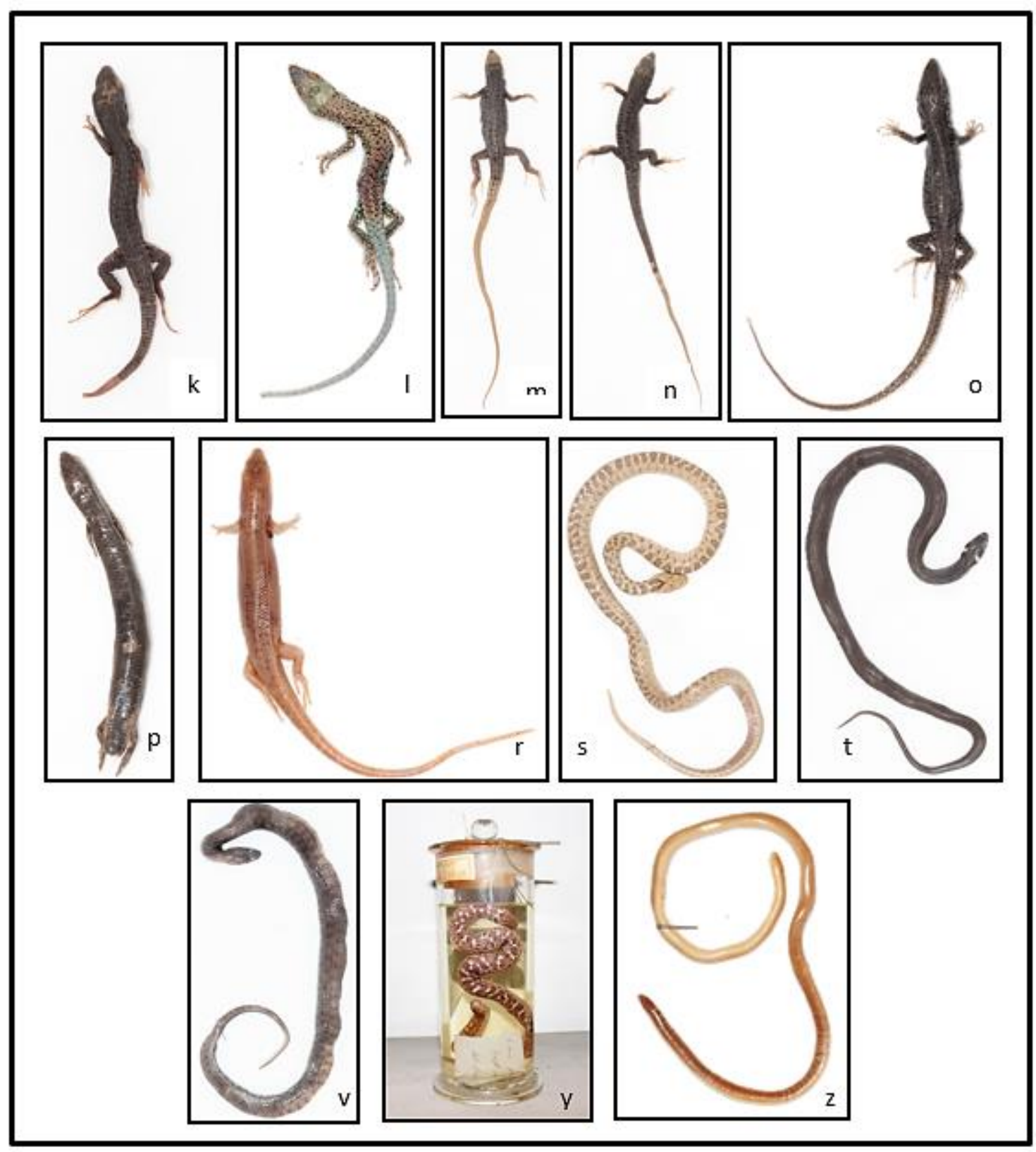

Figure 3. Photos of Reptilia species (k:Darevskia praticola, 1:Darevskia valentini, m:Ophisops elegans, $\mathrm{n}:$ Podarcis muralis, o:Podarcis taurica, p:Ablepharus kitaibelii, r:Trachylepis vittata, s:Zamenis hohenackeri, t:Natrix natrix, v:Natrix tessellata, y:Eryx jaculus, z:Xerotyphlops vermicularis).

Samples that localities and dates are unknown are not listed in Table 1. These species include: Eirenis modestus (MARTIN, 1838), Zamenis situla (LINNAEUS, 1758), Elaphe sauromates (PALLAS, 1811), Coronella austriaca LAURENTI, 1768 which were determined and published by Bodenheimer [7]. Mediodactylus heterocercus mardinensis (MERTENS, 1924) (Gaziantep), Elaphe sauromates (PALLAS, 1814) (Diyarbakır), Natrix tessellata vesseleri WERNER, 1903 (Gaziantep) and Vipera ammodytes LINNAEUS, 1758 (İstanbul) which dates are unknown collected by Kosswig and determined by Bodenheimer. The others: Mertensiella caucasica (WAGA, 1876), Chelonia mydas (LINNAEUS, 1758), Mauremys caspica (GMELIN, 1774), Emys orbicularis (LINNAEUS, 1758), 
Testudo graeca LINNAEUS, 1758, Pseudopus apodus (PALLAS, 1775), Dolichophis caspius (GMELIN, 1789), Telescopus fallax (FLEISCHMANN, 1831). And also the other species not from the Turkey's fauna with lacking information are not listed (Ambystoma sp., Proteus anguinus LAURENTI, 1768, Necturus sp., Telmatobius culeus (GARMAN, 1875), Alytes obstetricans (LAURENTI, 1768), Pelobates fuscus (LAURENTI, 1768), Pelophylax esculentus LINNAEUS, 1758, Sphenodon punctatus (GRAY, 1842), Crocodylus niloticus LAURENTI, 1768, Crocodylus sp., Draco volans LINNAEUS, 1758, Chamaeleo africanus LAURENTI, 1768, Chalcides boulengeri ANDERSON, 1892, Scincus scincus (LINNAEUS, 1758), Python sp.). With these species, the collection has reached 75 species.

Pholidosis and morphometric measurements of Parvilacerta parva (18.07.1985, Kurklareli) is recorded (Figure 2i.). Dorsal coloration is brown. Irregular dark spots line between parietal and hindleg. Occipital plates are present. Postnasal plates are two. Rostrale aren't connected to the nostril. Subralabial plates are eight. Four supralabial plates are in front of the subocular. The number of femoral openings are 12, transverse rows of ventralia are six. Number of subdigital lamella are 22 . Body scales have pronounced longitudinal keels and number of mid trunk scales are 32. Morphometric measurements follows pileus width is $6,54 \mathrm{~mm}$, pileus lenght is $10,01 \mathrm{~mm}$, head width is $4,41 \mathrm{~mm}$, head lenght is $10,26 \mathrm{~mm}$, head and body lenght is $45,10 \mathrm{~mm}$, foreleg lenght is $14,31 \mathrm{~mm}$, hind leg lenght is $22,29 \mathrm{~mm}$, distance lenght between foreleg and hind leg is $22,66 \mathrm{~mm}$.

\section{DISCUSSION}

ZMUI herpetological collection contains $40 \%$ of total known Amphibia species and $33 \%$ of total known Reptilia species as regards the total herpetofauna of Turkey. The oldest sample of Turkey is a snake (Malpolon monspessulanus (HERMANN, 1804)) which was collected from Istanbul in 1921 by Prof. Dr. Raymond Hovasse. The most important sample in the collection is Sphenodon punctatus, which is the only survivor of a group of reptiles that died out along with the dinosaurs and native to New Zealand [15]. With this study, Parvilacerta parva (BOULENGER, 1887) (18.07.1985, Kirklareli, Turkey) recorded from province Kurklareli for the first time. There is no record from Kurklareli in Thrace region up the now. However, this species was recorded in province Tekirdağ (Thrace Region) previously [16].

\section{CONCLUSION}

Istanbul University Zoology Museum is the oldest zoology museum in Turkey, therefore it has the oldest and valuable collections. Most of the species in the museum were collected in Anatolia by the scientists and colleagues. Distribution of Parvilacerta parva specimen is known mainly central and eastern Anatolia [17]. This study shows that the species, which was previously recorded by Venchi ve Bologna (1996) in only Tekirdağ, have distribution in Kırklareli in Thrace. However, the species is not recorded in Thrace in recent studies.

This study is significant in that it provides the distribution data of amphibia and reptiles in Turkey from 1921 to nowadays. Also, it has constituted the basic data that enables the comparison of differences in species distribution in time.

\section{ACKNOWLEDGEMENTS}

We thank Assoc. Prof. Murat Tosunoğlu (Çanakkale Onsekiz Mart University) for determining some species and providing articles. This work supported by the Research Fund of Istanbul University, project number: 25819 . 
Kaya and Özuluğ / Anadolu Univ. J. of Sci. and Technology C-Life Sci. and Biotech. 6 (2)-2017

\section{REFERENCES}

[1] Meriç N, Eryılmaz L, Özuluğ M. A catalogue of the fishes held in the Istanbul University, Science Faculty, Hydrobiology Museum. Zootaxa 2007; 1472: 29-54.

[2] Andreone F, Gavett1 E, Bovero S. Revised catalogue of the herpetological collection in Turin University II. Chelonia and Crocodylia, Bollettino. Museo Regionale di Scienze Naturali, Torino 2007; 24: 301-347.

[3] Cochran DM. The Herpetological Collections Made By Dr. Hugh M. Smith in Siam From 1923 to 1927. Proceedings of the US National Museum 1930; 77: 1-39.

[4] Glaw F, Franzen M. Type catalogue of amphibians in the Zoologische Staatssammlung München. Spixiana, 2006; 29: 153-192.

[5] Kohler J, Gusten R. Herpetological type specimens in the natural history collections of the museums in Darmstadt and Wiesbaden, German. Spixiana, 2007; 30: 275-288.

[6] Schmidt KP. Contributions to the herpetology of the Belgian Congo based on the collection of the American Museum Congo expedition, 1909 - 1915. Bulletin of The American Museum of Natural History 1923; 49: 1-191.

[7] Bodenheimer FS. Introduction into the Knowledge of the Amphibia and Reptilia of Turkey. Istanbul Universitesi Fen Fakültesi Mecmuası 1944; 9: 1-93.

[8] Mertens R. Amphibien and Reptilien aus Türkei. İstanbul Üniversitesi Fen Fakültesi Mecmuas1, 1952; 17: 41-75.

[9] Baran I, Atatür M. Türkiye Herpetofaunası (Kurbağa ve Sürüngenler). Çevre Bakanlığı, Ankara, 1998.

[10] Özuluğ O, Dökümcü N, Kaya N. İstanbul Üniversitesi Zooloji Müzesi’nin ülkemiz zooloji tarihindeki önemi. Ordu University Journal of Science and Technology 2013; 3: 69-78.

[11] Başoğlu M, Baran I. Türkiye Sürüngenleri Kısım II. Yılanlar. Ege Üniversitesi Fen Fakültesi Kitaplar Serisi, Bornova, İzmir, 1980.

[12] Özeti N, Yılmaz I. Türkiye Amfibileri. Ege Üniversitesi Basımevi, Bornova, İzmir, 1994.

[13] Sindaco R. Annotated Checklist of the Reptiles of the Mediterranean Countries, with Keys to Asiatic and African Species, Part 1-Turtles, Crocodiles, Amphisbaenians and Lizards (Reptilia). Annali del Museo Civico di Storia Naturale"G. Doria" 1998; 92: 85-190.

[14] Sindaco R, Venchi A, Carpaneto GM, Bologna MA. The reptiles of Anatolia: a checklist and zoogeographic analysis. Biogeographia 2000; 21: 441-481.

[15] Allen B. Tuatara Sphenodon. Herpetology 2007; 1-12.

[16] Venchi A, Bologna MA. Lacerta parva Boulenger, a new lizard species for the European fauna, Amphibia - Reptilia, 1996; 17: 89 - 90.

[17] Kumlutaş Y, Durmuş SH, Kaska Y, Öz M, Tunç MR. A Morphological and taxonomic study on Lacerta parva Boulenger, 1887 (Sauria: Lacertidae) from West Taurus, Turkey. Asiatic Herpetological Research, 2004; 10: $202-207$. 